\title{
Geochemical Fractions of Heavy Metals in Bottom Sediments of the Pobeda Hydrothermal Cluster in the Mid-Atlantic Ridge $\left(17^{\circ} 07^{\prime}-17^{\circ} 08^{\prime} \mathrm{N}\right)$
}

\author{
Liudmila Demina $^{1, *(\mathbb{D}}$, Irina Gablina ${ }^{2}$, Dmitry Budko ${ }^{1}$, Olga Dara ${ }^{1}$, Aleksandra Solomatina ${ }^{1}$, Nina Gorkova ${ }^{2}$ \\ and Tatiyana Smirnova ${ }^{2}$ \\ 1 Shirshov Institute of Oceanology, Russian Academy of Sciences (RAS), Nakhimovsky prosp. 36, \\ 117997 Moscow, Russia; dmitry.b-1990@yandex.ru (D.B.); olgadara@mail.ru (O.D.); \\ blackmaple@yandex.ru (A.S.) \\ 2 Geological Institute, Russian Academy of Sciences (RAS), Pyzhevsky per., 7/1, 119017 Moscow, Russia; \\ igabl@rambler.ru (I.G.); gorkova@ginras.ru (N.G.); tata_3000@inbox.ru (T.S.) \\ * Correspondence:1_demina@mail.ru
}

check for updates

Citation: Demina, L.; Gablina, I.; Budko, D.; Dara, O.; Solomatina, A.; Gorkova, N.; Smirnova, T.

Geochemical Fractions of Heavy Metals in Bottom Sediments of the Pobeda Hydrothermal Cluster in the Mid-Atlantic Ridge $\left(17^{\circ} 07^{\prime}-17^{\circ} 08^{\prime} \mathrm{N}\right)$. Minerals 2021, 11, 591. https:// doi.org/10.3390/min11060591

Academic Editors: Francisco J. González

Received: 30 April 2021

Accepted: 28 May 2021

Published: 31 May 2021

Publisher's Note: MDPI stays neutral with regard to jurisdictional claims in published maps and institutional affiliations.

Copyright: (c) 2021 by the authors Licensee MDPI, Basel, Switzerland. This article is an open access article distributed under the terms and conditions of the Creative Commons Attribution (CC BY) license (https:// creativecommons.org/licenses/by/ $4.0 /)$.
Abstract: In this study, to better understand the influence of hydrothermal processes on ore metal accumulation in bottom sediments, we examined distribution of $\mathrm{Fe}, \mathrm{Mn}, \mathrm{Cu}, \mathrm{Zn}, \mathrm{As}$, and $\mathrm{Pb}$ in core of metalliferous sediments from the Pobeda hydrothermal cluster, and in core of non-mineralized (background) carbonate sediments (located $69 \mathrm{~km}$ northwards). Mechanisms of $\mathrm{Fe}, \mathrm{Mn}, \mathrm{Cu}$, and $\mathrm{Zn}$ accumulation in sediments (12 samples) were evaluated based on sequential extraction of geochemical fractions, including a conditional mobile (F-1, exchangeable complex; F-2, authigenic Fe-Mn oxyhydroxides and associated metals; F-3, metals bound to organic matter/sulfides), and residual (F-4), fixed in crystalline lattices ones. The element contents were determined by the XRF and AAS methods, total carbon (TC) and total organic carbon (TOC) were determined using a Shimadzu TOC-L-CPN. Mineral composition and maps of element distribution in sediment components were obtained using the XRD and SEM-micro-X-ray spectrometry methods, respectively. In metalliferous sediments, according to our data, the major Fe mineral phase was goethite $\mathrm{FeOOH}(37-44 \%$ on a carbonate-free basis, $\mathrm{cb}$ ). In the metalliferous core, average contents (cfb), of Fe and Mn were 32.1\% and $0.29 \%$, whereas those of $\mathrm{Cu}, \mathrm{Zn}, \mathrm{Pb}$, and $\mathrm{As}$, were $0.74 \%, 0.27 \%, 0.03 \%$, and $0.02 \%$, respectively. Metalliferous sediments are enriched in $\mathrm{Fe}, \mathrm{Cu}, \mathrm{Zn}, \mathrm{Pb}$, and $\mathrm{As}$, relatively to background ones. The exception was $\mathrm{Mn}$, for which no increased accumulation in metalliferous core was recorded. Essential mass of Fe (up to $70 \%$ of total content) was represented by the residual fraction composed of crystallized goethite, aluminosilicates, the minerals derived from bedrock destruction processes mineral debris. Among geochemically mobile fractions, to $80 \%$ Fe of the (F-1 + F-2 + F-3) sum was determined in the form of F-2, authigenic oxyhydroxides. The same fraction was a predominant host for Mn in both metalliferous and background sediments (to 85\%). With these Fe and Mn fractions, a major portion of $\mathrm{Cu}, \mathrm{Zn}$, and $\mathrm{Pb}$ was associated, while a less their amount was found in sulfide/organic fraction. In the metalliferous sediment core, maximal concentrations of metals and their geochemically mobile fractions were recorded in the deeper core sediment layers, an observation that might be attributed to influence of hydrothermal diffused fluids. Our data suggested that ore metals are mostly accumulated in sediment cores in their contact zone with the underlying serpentinized peridotites.

Keywords: hydrothermal field Pobeda; Mid-Atlantic Ridge; metalliferous sediments; biogenic carbonates; ore metals; minerals; geochemical fractions

\section{Introduction}

The metalliferous sediments are unconsolidated deep-sea deposits that are formed in the volcanically active areas on the ocean floor [1-7]. The source of the metal-bearing matter in the metalliferous sediments is associated with volcanic rocks in the ocean crust. Most of 
the known accumulations of the metalliferous sediments, are confined to the Mid-Ocean Rift System and back-arc spreading areas of the World Ocean. Hydrothermal sediments are classified into two types: those derived from the plume precipitation (majority reported from ridge flanks), and those derived from mass wasting of the ore material close to active vent sites [8,9]. According to [6,10], about $5 \%$ of the hydrothermal ore-bearing matter that enters the ocean in the hydrothermal solutions, are accumulated within the massive bodies at the vents, and about $95 \%$ is deposited outside of them. The criteria to distinguish the metalliferous sediments are geochemical modules proposed by $[4,5]$.

A feature of the metalliferous deposits of the Mid-Atlantic Ridge (MAR) is that they are composed of the biogenic carbonate sediments. The acid hydrothermal fluids of diffusive type affect a distribution, preservation, and species composition of the plankton and benthic foraminifers, leading to a partial dissolution and metasomatic substitution of biogenic calcite with various hydrothermal minerals [11]. Microfossils of plankton foraminifers (fraction larger than $0.1 \mathrm{~mm}$ ) from carbonate sediments of the Ashadze-1 hydrothermal field $\left(13^{\circ} \mathrm{N}, \mathrm{MAR}\right)$, associated with ultramafic deep rocks, are characterized by a significant accumulation of $\mathrm{Fe}, \mathrm{Cr}, \mathrm{Ni}, \mathrm{Co}, \mathrm{Zn}, \mathrm{Cu}, \mathrm{Pb}$, and $\mathrm{Ag}$ relative to the specimens from background areas [12]. Trace element accumulation in shells of planktonic foraminifers occurs during the biomineralization by including them into the crystal lattice of calcite [13], as well as due to adsorption on the foraminiferal tests in sedimentation and post-sedimentation processes [14].

At the Mid-Atlantic Ridge, the seafloor massive sulfides deposits, are enriched in the ore metals $(\mathrm{Cu}, \mathrm{Zn}, \mathrm{As}, \mathrm{Au}, \mathrm{Ag}$, U, etc.), whose concentrations are much higher than those in the land-based volcanogenic massive sulfide $[15,16]$. The hydrothermal-derived oxyhydroxide sediments have been recently associated with the 2011-2012 underwater volcano eruption and the hydrothermal system established in the Canary Islands $[17,18]$. The hydrothermal micro-layers have been discovered within thick ferromanganese crusts in seamounts from the Atlantic Ocean, showing the influence of hydrothermal plumes during the growth process of ferromanganese deposits [19].

In recent years, a new type of the metalliferous and ore sediments formed by diffuse flows has been established while examining hydrothermal fields in the Russian exploration area at the Mid-Atlantic Ridge, $13^{\circ}-20^{\circ} 50^{\prime} \mathrm{N}$ [20-23]. In 2014-2015, during cruise 37 of R/V "Professor Logachev" organized by the Polar Marine Geological Exploration Expedition, the ore cluster Pobeda hosted in ultramafic rocks, was discovered. The Pobeda cluster's structure is composed of the mafic-ultramafic rocks, biogenic carbonate, metalliferous, and ore-bearing sediments [24,25]. Mineral composition and trace element admixtures in the massive sulfide ore changes with a distance from the high temperature vent fluids: pyrite, wurtzite, isocubanite, and sphalerite, dominated at foot of the black smoker's ore body, are replaced with marcasite-pyrite in diffusers developed in sediments [26,27].

The geochemical studies of the Pobeda hydrothermal sediments have revealed that the elemental composition was formed due to the interacting three factors: hydrothermal $(\mathrm{Fe}, \mathrm{Cu}, \mathrm{Pb}, \mathrm{As}, \mathrm{Zn})$; lithogenic, combining terrigenous and the minerals derived from bedrock destruction processes ( $\mathrm{Al}, \mathrm{Si}, \mathrm{Ti}, \mathrm{Mg}, \mathrm{K}$ ), and biogenic (Ca, $\mathrm{Sr}$ ) [28]. Input of $\mathrm{Si}$ into the metalliferous sediments was found to be related to aluminosilicate minerals (lithogenic factor), while the Si biogenic and hydrothermal origin was not excluded [29]. At the same time, information about the trace metal occurrence forms or geochemical fractions that are known to reflect a contribution of different processes and mineral carries to the ore metals accumulation in sediments, is a scarce enough. In the case of the Pobeda cluster's sediment cores, little is known about the relationship of different sediment components and the ore metal accumulation.

In this paper, based on the comparative analysis of the elemental and mineral composition of metalliferous sediments from the Pobeda hydrothermal cluster with the background ones, we aimed: (1) to determine the down-core distribution of $\mathrm{Fe}, \mathrm{Mn}, \mathrm{Cu}, \mathrm{Zn}$, and $\mathrm{Pb}$, as well as $\mathrm{CaCO}_{3}$ and TOC, (2) to quantify the geochemical fractions in sediments, based on the sequential chemical leaching; (3) to clarify mechanisms of metal accumulation using 
the micro-X-ray spectral analysis technique. Besides, given that in the organisms, the bioavailable forms of trace elements are mostly accumulated, it is of importance to evaluate their portion in total content of some toxic heavy metals from viewpoint of their potential risk for bottom fauna.

\section{Materials and Methods}

\subsection{Geological Setting and Sampling}

The Pobeda hydrothermal cluster is located at the Mid-Atlantic Ridge between $17^{\circ} 07^{\prime}$ and $17^{\circ} 08^{\prime} \mathrm{N}$ at the water depths between 1950 and $2400 \mathrm{~m}$ (Figure 1a) on the Eastern wall of the rift valley, whose slope is strongly dissected by numerous discharges and cracks (Figure 1b).

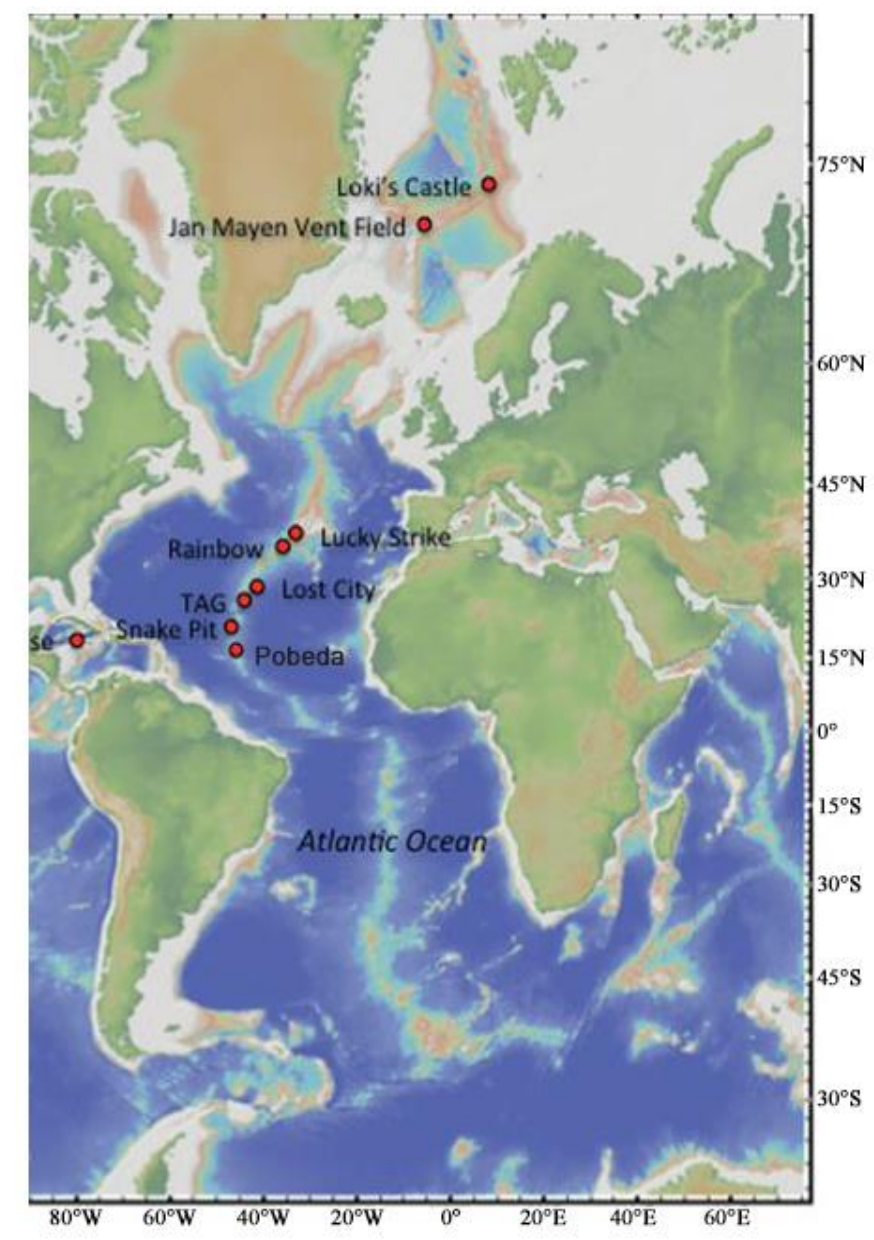

(a)

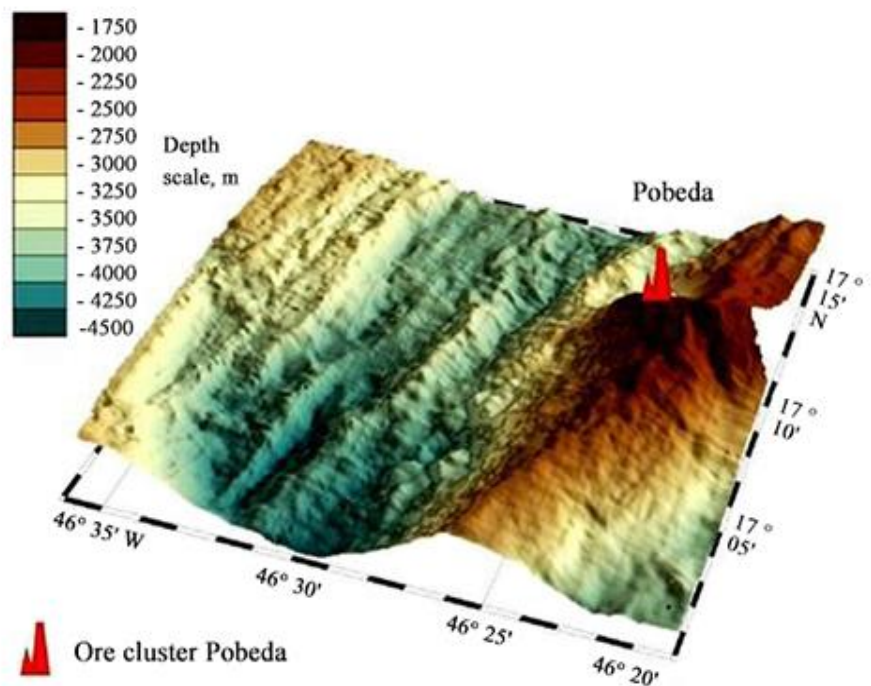

(b)

Figure 1. The Pobeda ore cluster's location among the known hydrothermal fields at the Mid-Atlantic Ridge (a) and scheme of the rift valley (b) (https:/ / motherboard-images.vice.com/content-images/contentimage/14339/1407427503312474.jpg, accessed on 31 May 2021).

The geological structure of the Pobeda cluster involves basalts, rocks of deep intrusive gabbro-peridotite complex, and bottom sediments. The largest spread are gabbroperidotites and bottom sediments, occupying more than half of the field area. The deep rocks are composed of the serpentinized and calcified peridotites, serpentinites, gabbroids, serpentine-chlorite rocks, and pyroxenites [24,25,30]. According to our data, the HoloceneUpper Pleistocene deposits are represented by carbonate biogenic coccolite-foraminiferal sediments, with admixture of the minerals derived from bedrock destruction processes, and pteropod detritus [22]. 
For this paper we investigated the two sediment cores. Core $184 \mathrm{k}\left(17^{\circ} 08.418^{\prime} \mathrm{N}\right.$, $2544 \mathrm{~m}$ depth), the 70-cm long, was composed of the metalliferous carbonate sediments located in the center of the Pobeda ore cluster. Core $215 \mathrm{k}\left(17^{\circ} 44.899^{\prime} \mathrm{N}, 3535 \mathrm{~m}\right.$ depth), the $110-\mathrm{cm}$ long, was located $69 \mathrm{~km}$ northwards the Pobeda cluster, this core was presented by the background carbonate sediments. Sediment cores were taken with a box-core sampler in an undisturbed state.

\subsection{Geochemical and Mineralogical Analyzes}

Geochemical partitioning of $\mathrm{Fe}, \mathrm{Mn}, \mathrm{Cu}$, and $\mathrm{Zn}$ in sediment cores was estimated based on sequential leaching procedure of the specimens (mass of $500 \mathrm{mg}$ ). A sequential leaching procedure was applied to separate the elements having different geochemical lability [31,32]. The following geochemical fractions were examined: F-1—an exchangeable complex which consists of elements adsorbed mainly onto the clay and carbonate particles, the desorbing solution was acetate buffer $\left(4 \mathrm{M} \mathrm{CH}_{3} \mathrm{COOH}+1 \mathrm{M} \mathrm{CH}_{3} \mathrm{COONa}\right)$ [33]; $\mathrm{F}-2$-amorphous authigenic Fe-Mn oxyhydroxides and related trace elements, the reduction reagent was $2 \mathrm{M} \mathrm{NH}_{2} \mathrm{OH} \cdot \mathrm{HCl}+4 \mathrm{M} \mathrm{CH}_{3} \mathrm{COOH}$ [34]; F-3-metals associated with organic matter and sulfides, the oxidation reagent was a mixture of $12 \mathrm{M} \mathrm{H}_{2} \mathrm{O}_{2}$ and $0.1 \mathrm{M}$ $\mathrm{HNO}_{3}$ [35]; $\mathrm{F}-4$-residual (complete acid decomposition with the mixture of concentrated $\mathrm{HCl}+\mathrm{HNO}_{3}+\mathrm{HF}$ ). The first three fractions allow to estimate a contribution of conditional geochemically labile metal fractions, while the fourth one, that contains refractory compounds (aluminum silicates, quartz, clastic minerals, crystallized Fe oxyhydroxides), is considered as a geochemically inert fraction. According to our mineralogical examination, in case of metalliferous and ore-bearing sediments, fraction F-4 contains not only quartz and aluminosilicates, but the crystallized goethite $(\mathrm{FeOOH})$ of the hydrothermal origin, as well as the fine debris of seabed rocks. For the leaching procedures, the Teflon and low density polyethylene vessels were used. Before the chemical treatment, samples were dried and powdered. Only the ultrapure reagents were used; the concentrated nitric acid was additionally distilled in the Teflon Sub boiling system Berghof BSB-939-IR. Blank concentrations were as follows ( $\left.\mu \mathrm{g} \mathrm{L}^{-1}\right)$ : $\mathrm{Fe}, \mathrm{Mn} 0.3$; $\mathrm{Cu}$ and $\mathrm{Zn} 0.1$. At all leaching stages, the proportion sample: leaching reagent was 1:2. The leaching procedure was performed in the ultrasonic bath at $70^{\circ} \mathrm{C}$ for $4 \mathrm{~h}$. After cooling, the sample solutions were centrifuged for $30 \mathrm{~min}$ at speed $3000 \mathrm{rpm}$. The supernatant liquid was collected with a plastic syringe-filter into a Teflon bottle, followed by evaporation of the sample solution to the wet salts, which were then dissolved with $2 \mathrm{~mL}$ of $1 \mathrm{M} \mathrm{HNO}_{3}$. The final volume of the solution $(15 \mathrm{~mL})$ was set with the deionized water. After the three leaching stages, the residual solid sample was subjected to complete acid destruction by use of Teflon vessels in a Speed Wave microwave oven (Berghof Products+Instruments, $\mathrm{GmbH}$, Mühlhausen, Germany) at $150^{\circ} \mathrm{C}$ for $3 \mathrm{~h}$. The metal concentrations in leachates were quiantified by the ICP-MS (Agilent 3500, Santa Clara, CA, USA). The effectiveness of the chosen procedure of sequential extraction was repeatedly tested by the European Community Bureau of References [36-38].

The elemental analysis of the bulk sediments (dried and powdered) was performed by the XRF method on the Spectroscan MAKS-GVM (Kortek Company, Moscow, Russia). The analysis accuracy was controlled with the Certified Reference Material of the National Institute of Standards of Canada SRM NIST 2702 (marine bottom sediments) with yielding deviation $0.7 \%$ to $9.5 \%$.

Mineralogical analysis of sediments was carried according to the standard methods of XRD diffractometry $[39,40]$ by use of a D8 ADVANCE diffractometer (Bruker AXC, Karlsrue, Germany), $\mathrm{Cu}-\mathrm{K} \alpha$, with Ni 0,02-filter, $40 \mathrm{kV}, 40 \mathrm{~mA}$, with linear detector LYNXEYE. Scanning in discrete mode in steps of $0.02^{\circ} \theta$, exposure of $4 \mathrm{~s} / \mathrm{step}$ in the range $2.0^{\circ}-70^{\circ} 2 \theta$, with rotation. For primary processing, interpretation of spectra, and calculation, the programs DIFFRAC.EVA, DIFFRAC.TOPAS (Quantitative Rietveld analysis, DIFFRAC.EVA V 5, DIFFRAC. TOPAS 5 version) was applied. Mass quantitative analysis was performed using corundum numbers from the ICDD database. The methods described were applied to identify clay minerals and determine their quantitative proportions. The identification of 
clay minerals was performed on oriented air-dried samples prepared from the clay fraction suspension separated from the sample in distilled water [39,40]. Subsequently, samples were saturated with ethylene glycol (for the diagnosis of minerals of the smectite group, as well as mixed-layered formations with swollen layers) and warmed at $550{ }^{\circ} \mathrm{C}$ (in cases of problems with the diagnosis of kaolinite and chlorite). Special cuvettes, being a kind of optical shutters for background scattering made of a single silicon crystal, were used for precision studies.

Maps of element distribution in sediment components were obtained by use of a scanning electron microscope equipped with an energy-dispersive spectrometry detector (SEM VEGA 3, TESCAN, Brno-Kohoutovice, Czech Republic). Contents of total carbon (TC) and total organic carbon (TOC) were determined using a Shimadzu TOC-L-CPN analyzer (Tokyo, Japan); total inorganic carbon (TIC) was calculated as a difference between TC and TOC. Statistical data processing was performed by the use of the software package Statistica 10 (TIBCO Software Inc., Palo Alto, CA, USA). Correlations between element concentrations in the sediment samples examined were calculated using Spearman's rank correlation coefficients (Spearman correlation; a non-parametric measure of the strength of two variables).

\section{Results}

\subsection{Distribution of $\mathrm{CaCO}_{3}$ and Major Elements Down the Cores}

Contents of total organic carbon (TOC), total inorganic carbon (TIC), and some major elements in the bulk sediments of $184 \mathrm{k}$ and $215 \mathrm{k}$ cores are listed in Table 1 . Core $184 \mathrm{k}$ is composed of brown coccolite-foraminiferal carbonate sediments soaked with iron hydroxides. Down the core, $\mathrm{CaCO}_{3}$ content showed a regular decrease from $77 \%$ to $20 \%$, particularly at depths of 40 and $70 \mathrm{~cm}$ (Figure 2a), where metalliferous sediments became the ore-bearing ones (due to strong growth of Fe contents, as can be seen in text below). In the background core 215k, the major portion of sediment is also presented by biogenic calcite $\left(\mathrm{CaCO}_{3}\right)$ with maximal content of $89 \%$ in surface layers and insignificant down the core decrease to $70 \%$ (Figure $2 \mathrm{~b}$ ). The both cores, $184 \mathrm{k}$ and $215 \mathrm{k}$, are depleted in TOC, whose average content is $0.15 \%$ and $0.08 \%$, correspondingly (Table 1 ). So, a vertical distribution pattern of $\mathrm{CaCO}_{3}$ differs noticeably in both cores. The lower average $\mathrm{CaCO}_{3}$ content, as well as it's the down-core regular significant decrease in the $184 \mathrm{k}$, might be considered as one of the metalliferous sediment features.

Table 1. The total organic carbon (TOC), total inorganic carbon (TIC), and some major elements in the bulk sediments of $184 \mathrm{k}$ and $215 \mathrm{k}$ cores from the hydrothermal cluster Pobeda.

\begin{tabular}{ccccccccc}
\hline Core & Depth, $\mathbf{c m}$ & TOC, $\%$ & TIC, $\%$ & Si, \% & Al, \% & Ca, \% & Mg, \% & Sr, \% \\
\hline \multirow{6}{*}{$184 \mathrm{k}$} & $0-5$ & 0.14 & 9.04 & 6.78 & 2.00 & 27.36 & 1.39 & 0.21 \\
& $20-25$ & 0.14 & 6.41 & 7.98 & 2.17 & 21.98 & 1.10 & 0.16 \\
& $30-40$ & 0.11 & 6.00 & 6.12 & 2.29 & 22.35 & 0.74 & 0.15 \\
& $40-45$ & 0.19 & 1.83 & 5.78 & 2.50 & 7.62 & 0.46 & 0.95 \\
& $60-65$ & 0.18 & 2.05 & 6.15 & 2.55 & 9.59 & 0.66 & 0.65 \\
& Average & 0.15 & 5.07 & 6.56 & 2.36 & 17.79 & 0.87 & 0.40 \\
\hline \multirow{6}{*}{$215 \mathrm{k}$} & $0-5$ & 0.17 & 10.63 & 6.50 & 1.86 & 28.30 & 0.98 & 0.19 \\
& $30-35$ & 0.05 & 9.97 & 6.90 & 1.95 & 27.90 & 0.95 & 0.16 \\
& $40-45$ & 0.07 & 8.67 & 10.44 & 2.41 & 24.71 & 1.01 & 0.13 \\
& $50-55$ & 0.04 & 8.75 & 8.68 & 2.10 & 26.69 & 0.96 & 0.14 \\
& $80-85$ & 0.07 & 8.34 & 9.98 & 2.48 & 24.09 & 0.97 & 0.12 \\
& $100-110$ & 0.09 & 8,79 & 9.83 & 2.39 & 24.86 & 0.96 & 0.14 \\
& Average & 0.08 & 9.19 & 8.75 & 2.20 & 26.09 & 0.97 & 0.15 \\
\hline
\end{tabular}




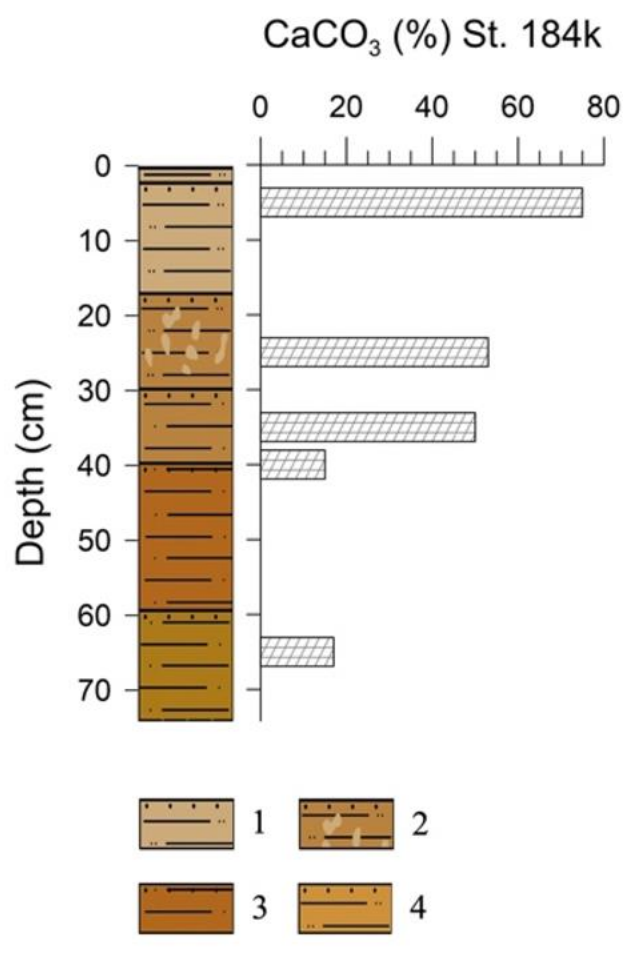

(a)

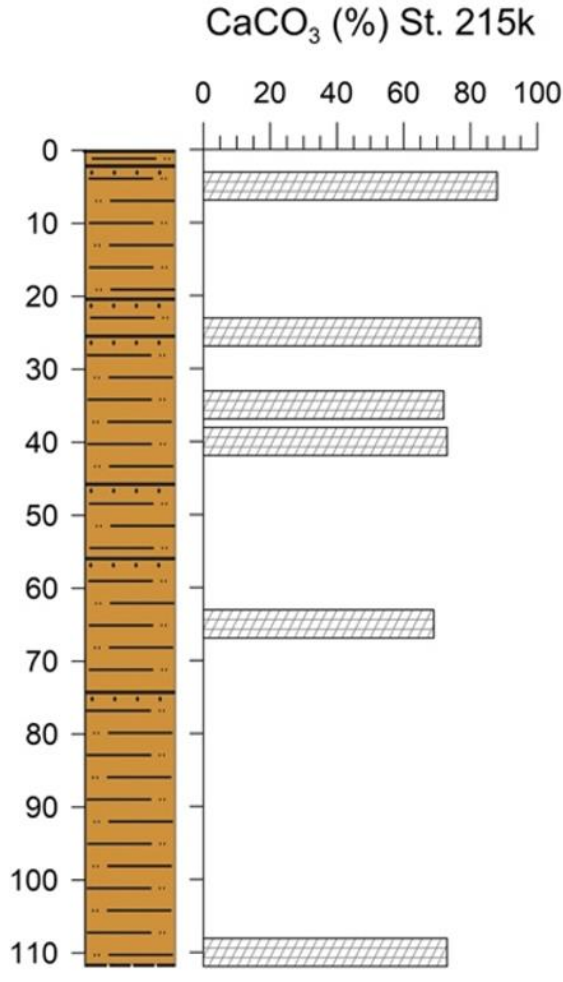

(b)

Figure 2. Lithology and the $\mathrm{CaCO}_{3}$ contents in sediment cores $184 \mathrm{k}(\mathbf{a})$, and $215 \mathrm{k}(\mathbf{b})$. Legend: 1 coccolite-foraminiferal, light-brown soft ooze, with sandy admixture; 2 -coccolite-foraminiferal, lightbrown, dense, silty-pelitic ooze, with bioturbation patches; 3 -homogenous coccolite-foraminiferal, dark-brown silty-pelitic ooze; 4-homogenous coccolite-foraminiferal, light-brown, dense, siltypelitic ooze with sandy admixtures.

At the same time, the down-core variation of lithogenous elements $\mathrm{Si}$ and $\mathrm{Al}$, as well as $\mathrm{Mg}$, is insignificant in both the cores (Table 1). The sum of Si and Al doesn't exceed 12\%, while sum of the carbonate forming elements TIC and $\mathrm{Ca}$, is three times more on average. This fact confirms a subordinate contribution of the lithogenous components in the studied sediments. Note that $\mathrm{Sr}$, being a geochemical analogue of $\mathrm{Ca}$, exhibits an inverse trend in vertical distribution: in the depth interval of $40-70 \mathrm{~cm}$, where the Ca content sharply decreased three times, content of Sr increased three times comparing to the above layer.

\subsection{Distribution of the Ore Metals in Two Cores}

One of the criteria for distinguishing metalliferous sediments is a geochemical module, based on a proportion between $(\mathrm{Fe}+\mathrm{Mn})$ and lithogenous components. According to [4], in metallifeous sediments, a value of $(\mathrm{Fe}+\mathrm{Mn}) / \mathrm{Al}$ ratio exceeds 2.5. According to calculated values from Table 1 and Table S1, the Boström module ranges from 2.9 to 12.7 in core $184 \mathrm{k}$ (Table S1), that confirms its belonging to metalliferous sediments. Maximal values of this module were calculated for the interval of $40-70 \mathrm{~cm}$ of $184 \mathrm{k}$ core, where Fe content exceeded $30 \%$, cfb. Taking into account the terminology definition [5,41], the lower part of this core refers to the ore-bearing sediments. At the same time, throughout the core 215k, the Boström module's values changed 1.1 to 1.7 (Table S1).

Since carbonate material constitutes a significant proportion of the sediment studied (Figure 3), we have recalculated concentrations of metals for a carbonate free base (cfb). The average ore metal concentrations in these two cores on $\mathrm{cfb}$ are listed in Table 2. Comparing these data, one can see that metalliferous sediments, core $184 \mathrm{k}$, are enriched in $\mathrm{Fe}, \mathrm{Cu}, \mathrm{Zn}$, $\mathrm{Pb}$, and As, 2 to 5 times, comparing to the background core 215k, as well to the pelagic clays. On the contrary, in the background sediments, where Mn average content is about twice 
as much, a ratio $\mathrm{Fe} / \mathrm{Mn}$ (5.90) corresponds to that for pelagic clays (5.96). The depletion in $\mathrm{Mn}$ and enrichment in $\mathrm{Fe}, \mathrm{Cu}, \mathrm{Pb}, \mathrm{As}, \mathrm{Zn}$ of metalliferous sediments from the Pobeda cluster was observed in [28].

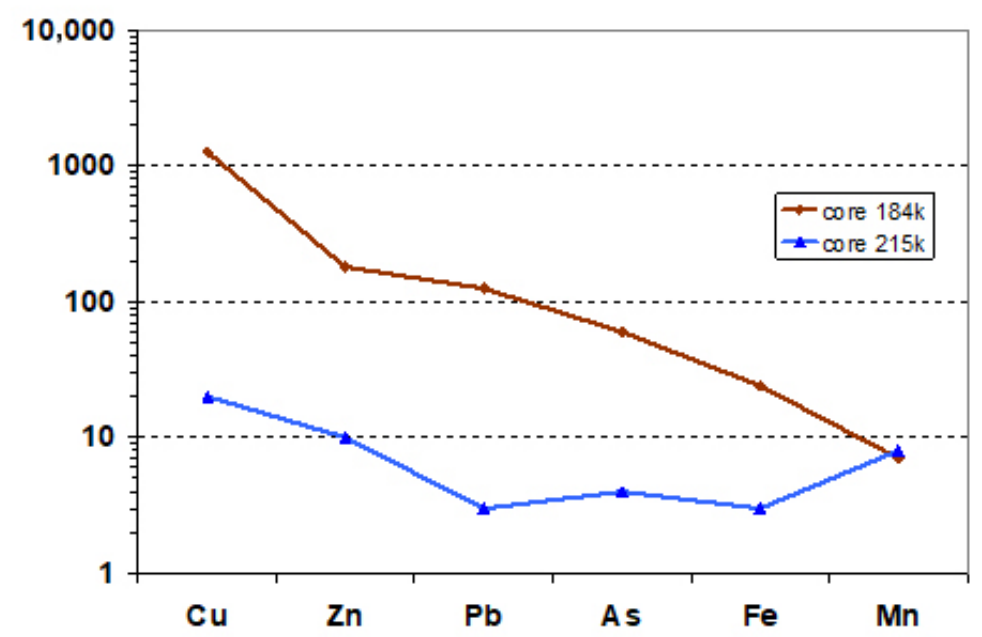

Figure 3. Comparison of the enrichment factor (EF) of some heavy metals and As in the ore- bearing $184 \mathrm{k}$ and background $215 \mathrm{k}$ cores.

The most contrasting metal enrichment of core $184 \mathrm{k}$ was detected by using the enrichment factor $\mathrm{EF}=\left(\mathrm{El}_{i} / \mathrm{Al}\right)_{\text {sample }} /(\mathrm{El} / \mathrm{Al})_{\mathrm{UCC}}$, where $\left(\mathrm{El}_{i} / \mathrm{Al}\right)_{\text {sample }}$-ratio of the average contents of the $i$-element and $\mathrm{Al}$ in sediment sample, $\left(\mathrm{El}_{i} / \mathrm{Al}\right)_{\mathrm{UCC}}$ - the same for the Upper Continental Crust [42]. In the ore-bearing core 184k, the maximal $\mathrm{EF}$ was calculated for $\mathrm{Cu}$ (1270), while for the rest of metals EF values were much lower: $180(\mathrm{Zn}), 125(\mathrm{~Pb}), 60(\mathrm{As})$, 24 (Fe) (Figure 3). The background core 215k is also enriched in metals relatively UCC, however, its EF values are significantly lower. Note that $\mathrm{Mn}$ is the only metal whose EF values were the same $(\mathrm{EF}=8)$ for in both sediment cores.

Table 2. Average contents of the ore metals (\%, carbonate free base) in $184 \mathrm{k}$ and $215 \mathrm{k}$ in comparison to the pelagic clays [43].

\begin{tabular}{ccccccc}
\hline & Fe \% & Mn \% & Cu ppm & Zn ppm & Pb ppm & As ppm \\
\hline 184k & 32.1 & 0.29 & 7438 & 2692 & 328 & 196 \\
215k & 2.86 & 0.63 & 620 & 408 & 88 & 109 \\
Pelagic clays [43] & 6.08 & 1.02 & 387 & 248 & 89 & 19 \\
\hline
\end{tabular}

The distribution of the ore metals' bulk contents and those for $\mathrm{cfb}$, in two cores is displayed at Figure 4.

In the ore-bearing core $184 \mathrm{k}$, the Fe contents began to grow at the depth of $35 \mathrm{~cm}$ reaching up to $40 \%$ (on the $\mathrm{cfb}$ ) in the basal layer $65-70 \mathrm{~cm}$ (Figure $4 \mathrm{a}$ ). A significant increase in the $\mathrm{Cu}, \mathrm{Zn}, \mathrm{Pb}$, and As contents, expressed in both natural bulk sediments, and $\mathrm{cfb}$, was detected also at the depth of $35 \mathrm{~cm}$, which continued down the core. Note, that at the same horizon, a sharp decrease in $\mathrm{CaCO}_{3}$ content was recorded (Figure 2a). At the same time, in background core 215k, the ore metals displayed another distribution pattern: $\mathrm{Fe}, \mathrm{Cu}, \mathrm{Zn}, \mathrm{Pb}$, and As contents (cfb) are decreased gradually, while their contents, expressed in both natural bulk and $\mathrm{cfb}$ ) showed no change down the core (Figure $4 \mathrm{~b}$ ). It is of interest, that Mn displayed a close distribution pattern in both the cores, namely, an increase only in the surface layer; the latter was likely caused by the diagenetic process. 
a) $\quad \mathrm{Fe}(\%)$

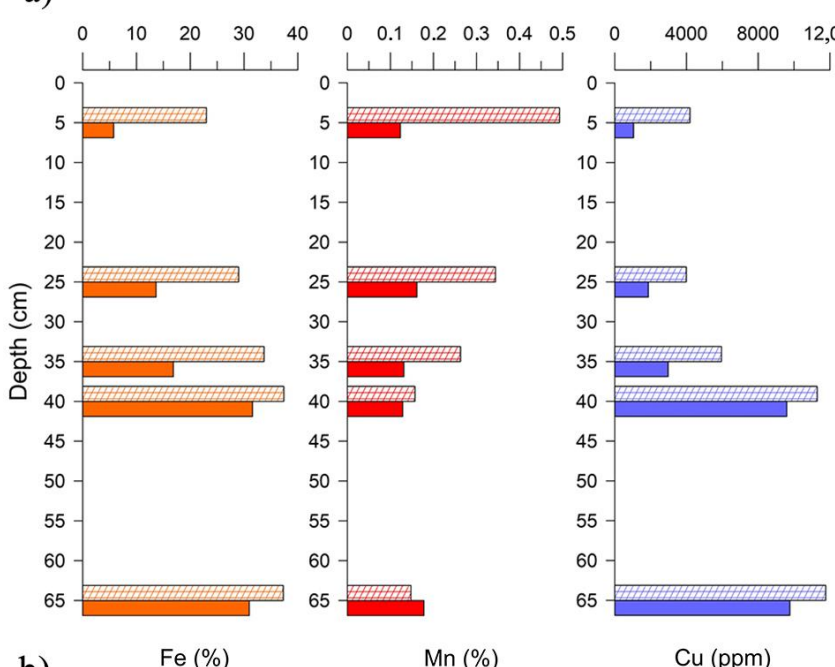

b)

$\mathrm{Mn}(\%)$

$\mathrm{Cu}(\mathrm{ppm})$
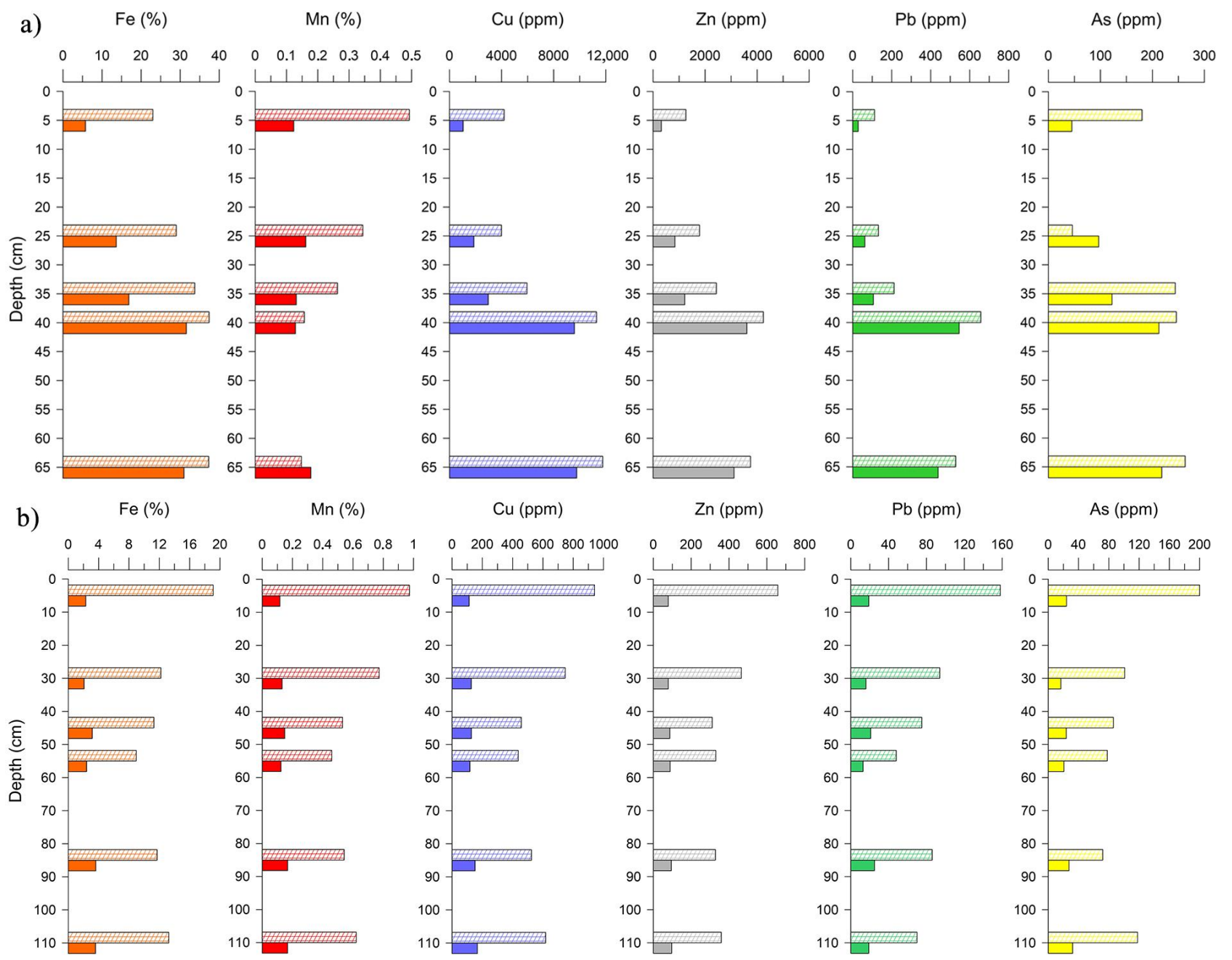

As (ppm)

Figure 4. Down-core metal distribution in 184k (a) and the background 215k (b) sediment cores. Metal contents in bulk sediment are shown with dense fill, while those on the carbonate free basis (cfb)—fill with hatching.

\subsection{Distribution of Geochemical Fractions of Metals in Two Cores}

The heavy metal partitioning between geochemical fractions allowed us to quantify a contribution of conditional labile fractions (F-1, F-2, and F-3) versus refractory compounds (F-4) into the metal accumulation in sediments. In a geochemically labile lithogenic fraction, elements occur in the exchangeable complex, associated with the authigenic amorphous Fe-Mn oxyhydroxides, as well as bound to organic matter or sulfides. In lithogenic fraction, elements are fixed in the crystalline structure of minerals. Distribution of selected geochemical fractions in $184 \mathrm{k}$ and $215 \mathrm{k}$ cores (Figure 5), suggested that the major amount of Fe (up to $70 \%$ of total content) was represented by the refractory F-4 fraction. From our data on mineral composition, in case of $\mathrm{Fe}$, this fraction is composed of crystallized goethite, as well as of clay, clastic, and the minerals derived from the bedrock destruction processes. Among geochemically mobile fractions (F-1, F-2, and F-3), to $90 \%$ Fe of the (F-1 + F-2 + F-3) sum was determined in the form of F-2, authigenic oxyhydroxides. Manganese is the most labile metal, since the Mn-oxyhydroxides fraction F-2 provided a predominant portion ( $55 \%$ to $85 \%$ ) of its amount in both cores (Table S1, Figure 5).

In metalliferous sediment core $184 \mathrm{k}$, the higher concentrations of $\mathrm{Fe}, \mathrm{Zn}$, and $\mathrm{Cu}(3$ to 5 times comparing to overlying layers), as well as their geochemically mobile fractions were recorded in the deeper layers, an observation that might be attributed to influence of hydrothermal diffused fluids. At the same time, in the background core $215 \mathrm{k}$, proportion between different fractions did not changed noticeably in the down-core metal distribution. 
Note that to $25 \%$ of total content of $\mathrm{Zn}$ and to $30 \%$ that of $\mathrm{Cu}$ are associated with the Fe amorphous authigenic oxyhydroxides fraction. The organic fraction did not exceed $10 \%$ of majority of metals (Figure 5). The exception is $\mathrm{Zn}$ in the core $215 \mathrm{k}$ where this fraction amounted a noticeable portion (to $60 \%$ of $\mathrm{Zn}$ total content) in surface layers.
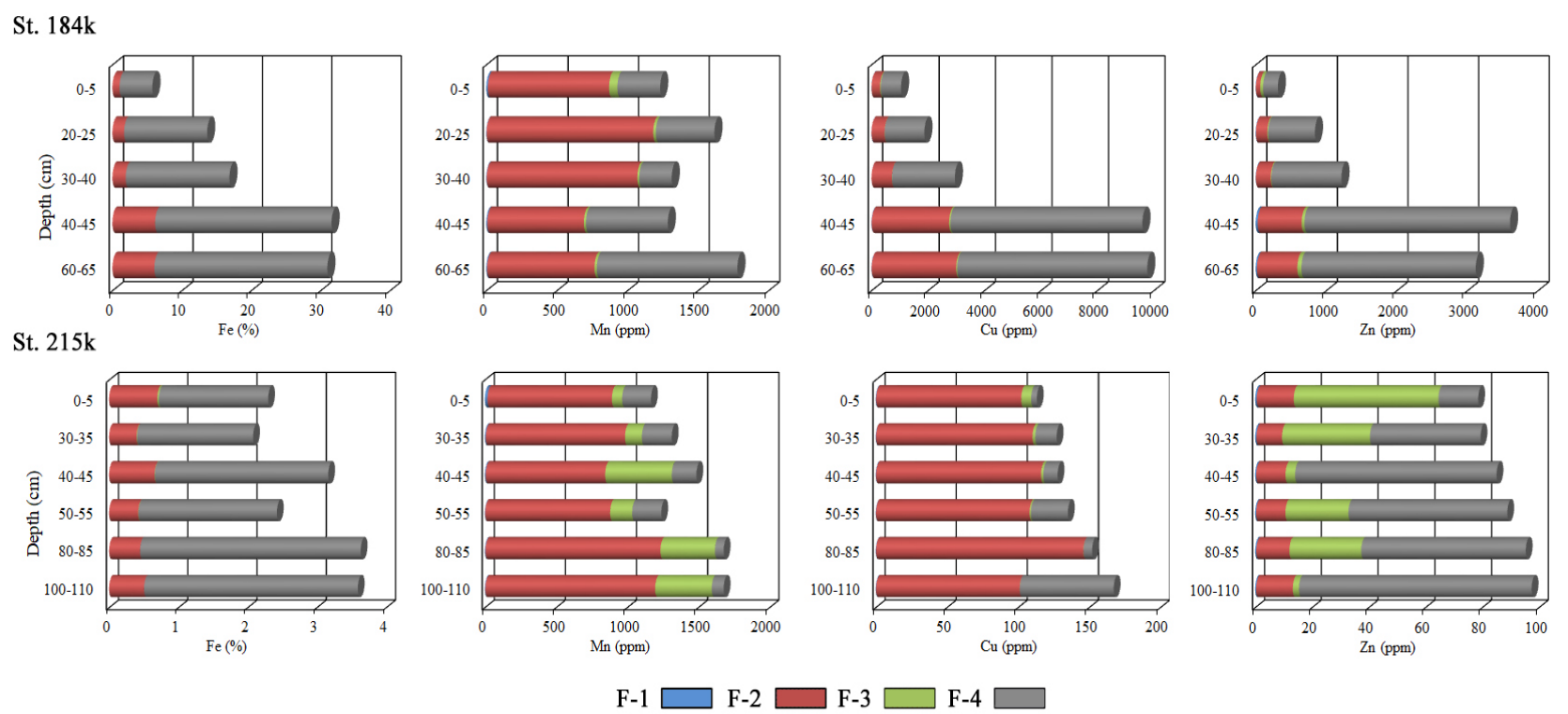

Figure 5. Geochemical fractions of metals in the metalliferous (St.184k) and background (St. 215k) cores. Fractions: F-1, exchangeable elements adsorbed mainly onto the clay and carbonate particles; F-2, authigenic Fe-Mn hydroxides and related trace elements; F-3, bound to organic matter or sulfides; F-4, refractory, metals fixed in crystalline lattices of mineral particles.

A sum of conventional labile fractions (F-1 + F-2 + F-3) of elements, is considered as a bioavailable portion that is predominantly accumulated by the bottom fauna. In Table S4, there are calculated data on the sum (F-1 + F-2 + F-3) of total contents for some heavy metals. While comparing the two cores, one can see that in the background sediments $215 \mathrm{k}$, percentages of bioavailable forms of a potentially toxic heavy metals $\mathrm{Zn}$ and $\mathrm{Cu}$ is 2 to 3 times higher than those in metalliferous core (Figure 6). Thus, in the latter we might suppose a reduced bioaccumulation of $\mathrm{Zn}$ and $\mathrm{Cu}$. At the same time, a percentage of the Fe and Mn bioavailable fractions doesn't differ significantly between two sediment cores.

\subsection{Mineral Composition of the Sediments in Two Cores}

The XRD data on the mineral composition in the natural bulk sediments (grain-size $>0.05 \mathrm{~mm}$ ) for cores $215 \mathrm{k}$ and $184 \mathrm{k}$ are listed in Table S2. The major part of minerals in core $184 \mathrm{k}$ is presented by calcite, whose content reached $77 \%$ in the upper layers, exhibiting a decrease down the core. These values of $\mathrm{CaCO}_{3}$ contents and those determined above by the TIC analysis (Figure 2a), are in a rather good agreement. The main Fe mineral phase was goethite $\mathrm{FeOOH}(37-44 \%$ on a carbonate-free basis, cfb). From data of the SEM-micro-X-ray images, amorphous Fe-Mn oxyhydroxides, are present in sediments. The XRD analysis identified also an admixture of pyrite, and a rather small quantities $(\leq 10-12 \%)$ of talc, serpentine (fragments of changed ultra-mafic rocks), quartz, and the clay minerals (smectite). A total amount of these minerals increased down the core, reaching up to $50 \%(\mathrm{cfb})$ in the basal layer. At the same time, there were no fragments of feldspars, pyroxenes, and amphiboles. In the background core $215 \mathrm{k}$, the XRD analysis revealed the predominance of calcite (to $86 \%$ ), while a much less portion was presented by terrigenous minerals and those derived from the bedrock destruction processes, composed of albite, potassium feldspars, pyroxenes, amphiboles, quartz, talc, serpentine, chlorite, kaolinite, illite, smectite, and palygorskite. 


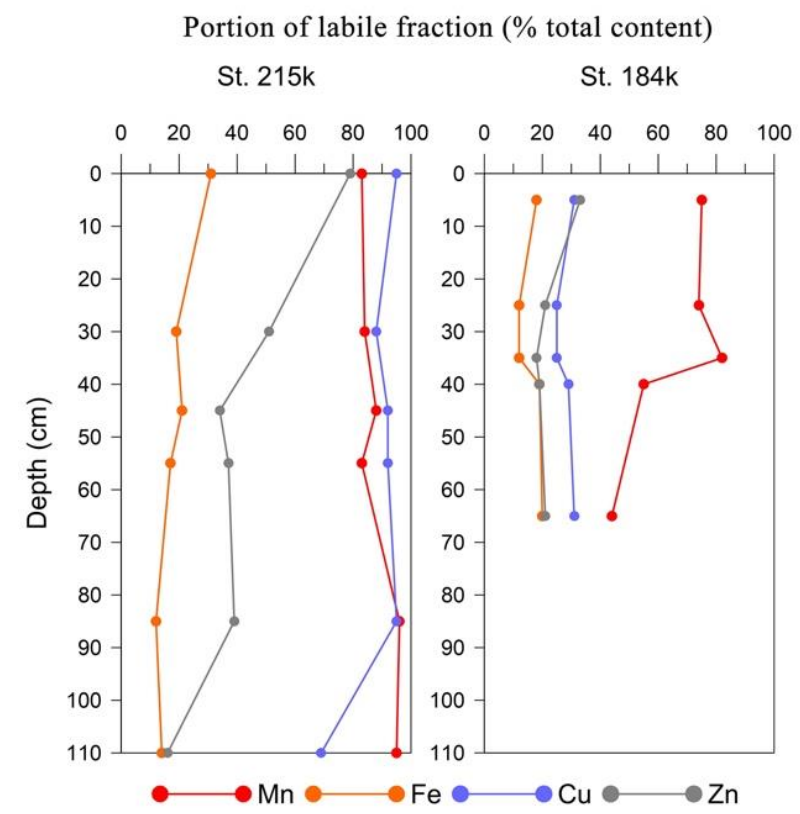

Figure 6. The down-core distribution of the labile fractions' sum (F-1 + F-2 + F-3) of $\mathrm{Cu}, \mathrm{Zn}, \mathrm{Fe}$, and $\mathrm{Mn}$, in the ore-bearing $184 \mathrm{k}$ and background $215 \mathrm{k}$ sediment cores.

3.5. Data on SEM-Micro X-ray Spectral Analysis of Selected Specimens from the Ore-Bearing and Background Sediment Cores

Maps of the element distribution in sediment components were obtained by use of SEM micro-X-ray spectral analysis. From our data, in core $184 \mathrm{k}$, at depths of $38-42 \mathrm{~cm}$ and 65-70 cm Fe-oxyhydroxides composed a major portion of sediments, forming both the finely, and the coarser dispersed isometric particles (Figures 7 and 8).
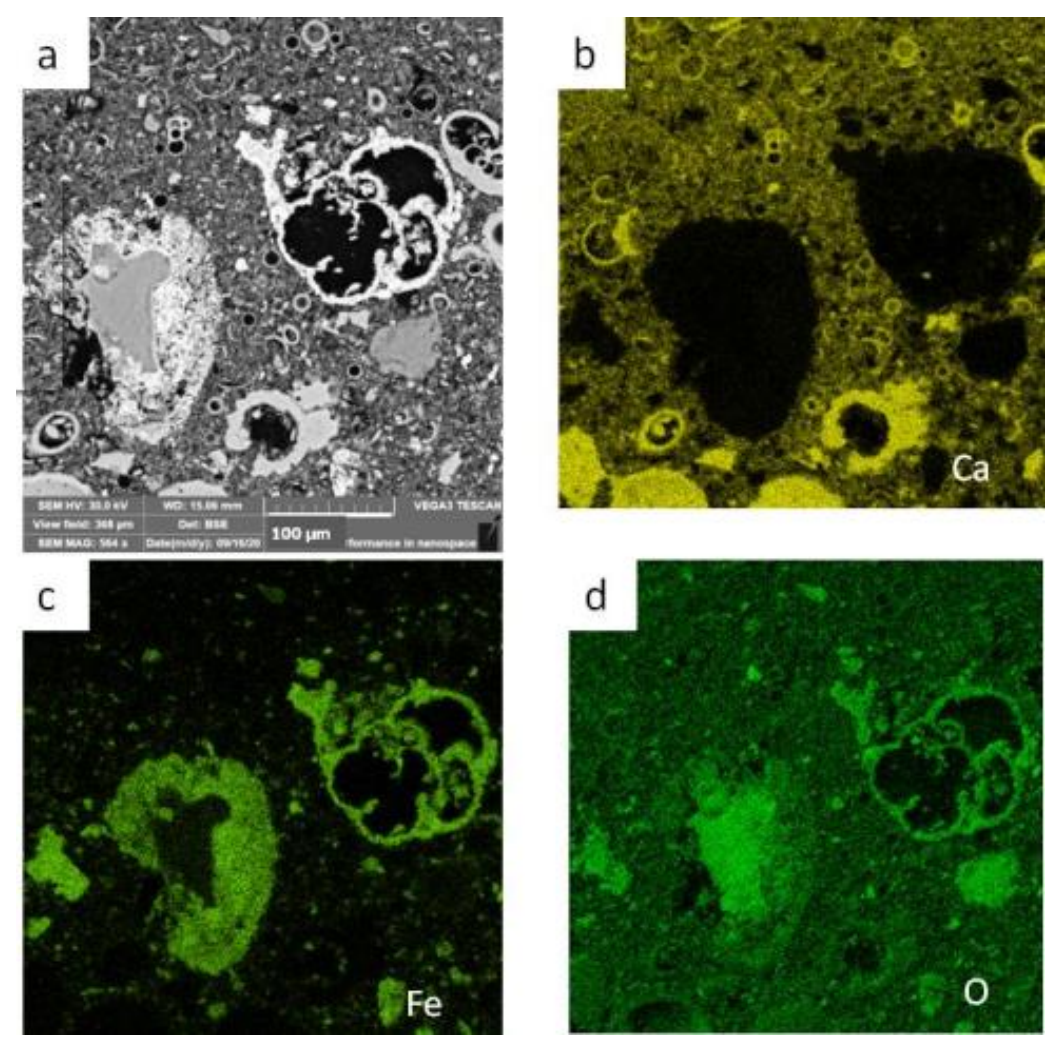

Figure 7. The SEM images of core 184k, the sediment layer of $38-42 \mathrm{~cm}$; (a) back scattered electrons' image; b-d, maps of the element distribution: (b) Ca; (c) Fe; (d) O. 

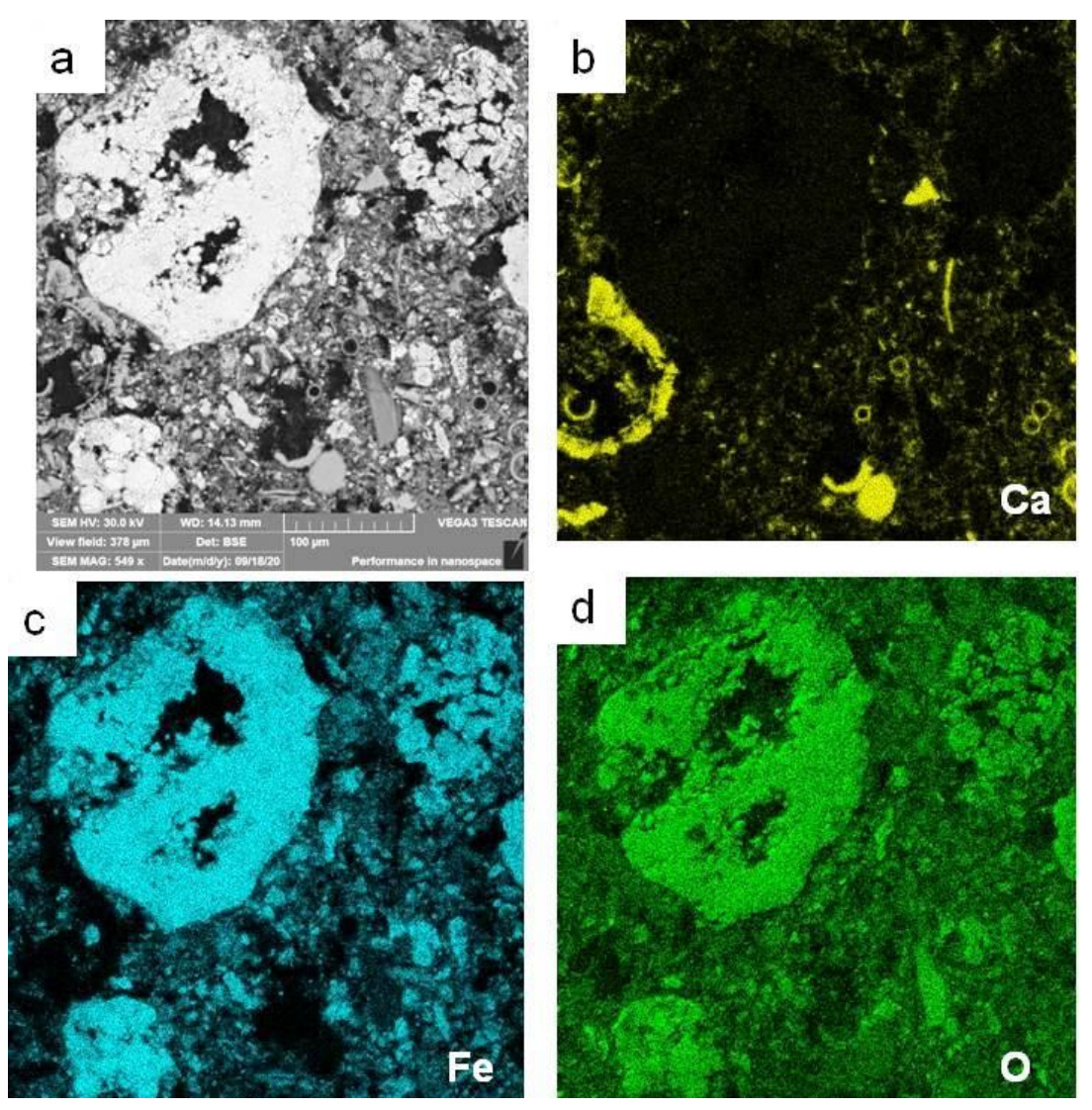

Figure 8. The SEM images of core 184k, the sediment layer of $65-70 \mathrm{~cm}$; (a) back scattered electrons' image; b-d, maps of the element distribution: (b) Ca; (c) Fe; (d) O.

These particles by shape and size (to $0.2 \mathrm{~mm}$ ) (Figures $7 \mathrm{a}$ and $8 \mathrm{a}$ ), as well as by $\mathrm{Ca}$ and oxygen distribution maps (Figure $7 \mathrm{~b}, \mathrm{~d}$ and Figure $8 \mathrm{~b}, \mathrm{~d}$ ), correspond to that of foraminiferal $\mathrm{CaCO}_{3}$ tests. The $\mathrm{Fe}$ and oxygen distribution maps (Figures $7 \mathrm{c}$ and $8 \mathrm{c}$ ) depict a calcite foraminiferal shell shape, while those of $\mathrm{Fe}$ and $\mathrm{Ca}$ exhibit an inverse picture. These data support our suggestion about a substitution of $\mathrm{Ca}$ in foraminiferal tests with $\mathrm{Fe}$ oxyhydroxides, mainly goethite.

At the same time, in the background core, $215 \mathrm{k}$, at the depth of 100-110 cm, distribution maps exhibit a clear association of Ca (Figure 9a,b) and oxygen (Figure 8d) with foraminiferal tests, while for $\mathrm{Fe}$, no such a relation was observed (Figure 9c). Angular and irregularly shaped lithogenic particles (fragments of aluminosilicates) are traced by oxygen (Figure $9 \mathrm{~d}$ ), as well as by $\mathrm{Al}$ and $\mathrm{Si}$ (Figure $9 \mathrm{e}, \mathrm{f}$ respectively).

\subsection{Correlation Relationships between Elements}

Results of the Spearman correlation analysis between the ore metals (contents in the $\mathrm{cfb}$ ) and the other elements (contents in bulk sediment) are in Table S3. In the orebearing core $184 \mathrm{k}$, the significant correlation coefficients $\left(R^{2}, p<0.05\right)$ was calculated for the following pairs of ore elements: Fe- $\mathrm{Zn}, 0.875 ; \mathrm{Fe}-\mathrm{Cu}, 0.746$; $\mathrm{Fe}-\mathrm{Pb}, 0.522 ; \mathrm{Fe}-\mathrm{As}$, 0.352; $\mathrm{Cu}-\mathrm{Zn}, 0.932$; Fe-Mn, -0.969, $\mathrm{Mn}-\mathrm{Zn},-0.865 ; \mathrm{Mn}-\mathrm{Cu},-0.672 ; \mathrm{Mn}-\mathrm{Pb},-0.717$; Mn-As, 0.273 . These values (except of Fe-As and Mn-As) indicate a significant positive relationship between distribution of $\mathrm{Fe}, \mathrm{Zn}, \mathrm{Cu}$, and $\mathrm{Pb}$, on the one hand, and a significant negative relationship between $\mathrm{Fe}$ and $\mathrm{Mn}$, as well as between $\mathrm{Mn}$ and $\mathrm{Zn}, \mathrm{Cu}$, and $\mathrm{Pb}$, on the other hand (Table S3). On the contrary, in 215k background core, no positive relations between Fe and other ore metals was found, but the latter showed the significant positive correlation with $\mathrm{Mn}: \mathrm{Mn}-\mathrm{Zn}, 0.919 ; \mathrm{Mn}-\mathrm{Cu}, 0.922 ; \mathrm{Mn}-\mathrm{Pb}, 0.896 ; \mathrm{Mn}-\mathrm{As}, 0.938$. So, we might conclude that in the ore-bearing sediments, the main carriers of $\mathrm{Zn}, \mathrm{Cu}, \mathrm{Pb}$ (and to a lesser extent $\mathrm{As}$ ), are the mineral phases of iron oxyhydroxides, while in the background core, these elements 
are associated with manganese oxyhydroxides. Correlation coefficients for $\mathrm{CaCO}_{3}, \mathrm{Ca}, \mathrm{Mg}$, and $\mathrm{Sr}$ (in natural bulk sediment) were as follows: $\mathrm{Ca}-\mathrm{CaCO}_{3}=0.954$, that is quite natural for biogenic carbonate sediments. At the same time, a significant negative correlation $\mathrm{Mg}-\mathrm{Ca}=-0.974, \mathrm{Ca}-\mathrm{Sr}=-0.844$, and $\mathrm{Sr}-\mathrm{CaCO}_{3}=-0.72$, likely indicates a significantly different process of $\mathrm{Ca}$ and $\mathrm{Sr}$ accumulation in sediments.
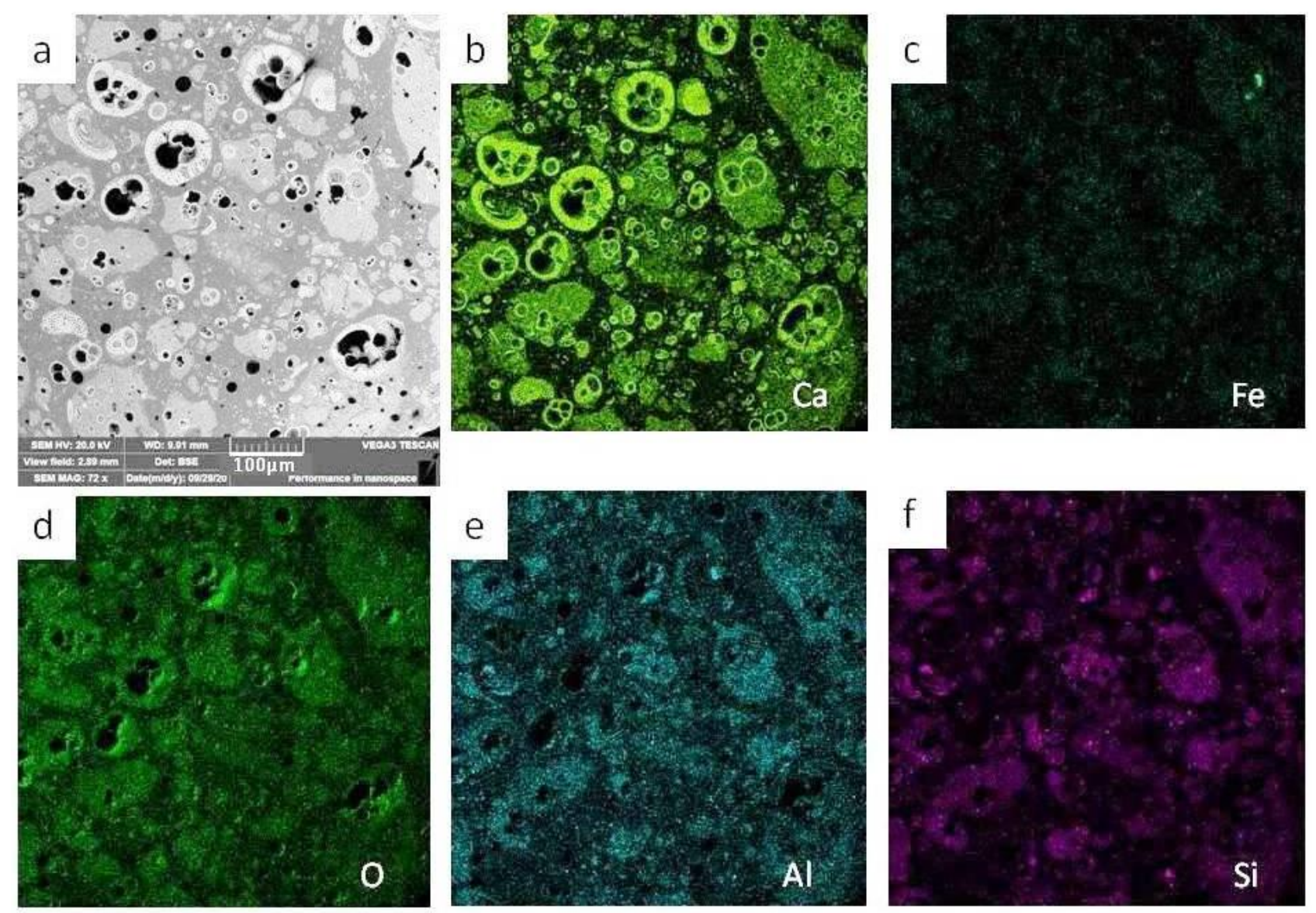

Figure 9. SEM images of the background core 215k, the sediment layer of 100-110 cm; (a) back scattered electrons image; b-e: maps of elements' distribution: (b) Ca, (c) Fe, (d) O, (e) Al, (f) Si. Dark areas are the epoxy resin cementing fragments of clay-carbonate sediment with microfossils.

\section{Discussion}

The above noted vertical decrease in content of $\mathrm{CaCO}_{3}$ in the $184 \mathrm{k}$ core (Figure $2 \mathrm{a}$ ) can be considered as one of the characteristic features for the metalliferous sediments of the Pobeda ore cluster. Core $184 \mathrm{k}$ meets geochemical criterion for distinguishing metalliferous sediments [4], and its lower part, starting from depth of $35 \mathrm{~cm}$ and deeper, where the Fe $\mathrm{cfb}$ contents exceeded $30 \%$, in accordance to terminology definition $[5,41]$ refers to the ore-bearing sediment. At the same depth of $184 \mathrm{k}$ core, a significant growth of the Fe, $\mathrm{Zn}, \mathrm{Cu}, \mathrm{Pb}$, and As, contents. Their average contents exceeded 2 to 10 times those for background core $215 \mathrm{k}$ and pelagic clays, while $\mathrm{Mn}$, on the contrary, in 184k core, exhibited the decreased average (by a factor of 2) comparing to background 215k core. These our observations are close to those of [28] for the Pobeda hydrothermal sediments which are enriched in $\mathrm{Fe}, \mathrm{Cu}, \mathrm{Pb}, \mathrm{As}, \mathrm{Zn}$, and $\mathrm{Cr}$, but depleted in $\mathrm{Mn}$.

Taking into account the fact that in hydrothermal fluids that are derived from the circulation systems hosted in ultramafic rocks, the Mn concentration is much higher compared to that of Fe [8], a question arose about the reasons for difference in the Fe and $\mathrm{Mn}$ contents and vertical distribution patterns in metalliferous sediments. An excess of Fe was attributed to entirely hydrothermal processes, while the major part of Fe was 
precipitated from fluids within hydrothermal fields [5]. At the same time, a depletion in Mn of metalliferous sediments was caused by an extremely low coefficient of the Mn differentiation with a distance from hydrothermal vent edifice, this coefficient for $\mathrm{Mn}$ is 3 to 4 order of magnitude lower than that for Fe [7]. Such a difference was related to a weak fixation of $\mathrm{Mn}$ in the ore material that resulted to the Mn transport beyond the hydrothermal field [7]. Based on our earlier data, an additional reason for the metalliferous sediments' depletion in $\mathrm{Mn}$ is proposed. Microfossils of planktonic foraminifers, selected from sediments of hydrothermal field Ashadze- $1\left(13^{\circ} \mathrm{N}\right.$, MAR) hosted in ultramafic rocks, revealed no elevated accumulation of $\mathrm{Mn}$ in specimens sampled nearby vent, unlike $\mathrm{Fe}, \mathrm{Ni}$, $\mathrm{Co}, \mathrm{Cr}$, and $\mathrm{Ag}$, whose contents were to 10 times higher comparing to the specimens from background area. Meanwhile, the elevated content of many elements $(\mathrm{Cd}, \mathrm{Co}, \mathrm{Cr}, \mathrm{Cu}, \mathrm{Fe}$, $\mathrm{Mn}, \mathrm{Ni}, \mathrm{As}$, and $\mathrm{Pb}$ ) in foraminiferal shells of Globigerina, Globorotalia, Globigerinoides, and Orbulina, is a common case for the Holocene-Upper Pleistocene sediments of the Central Atlantic, sampled far from MAR; accumulation of these metals was attributed to the metal adsorption on the surface of calcite tests and inside their pores, as well to the diagenetic processes [14].

As it is known, there is a difference in the $\mathrm{Fe}$ and Mn behavior in the redox processes, $\mathrm{Fe}^{2+}$ is more sensitive to oxidation than $\mathrm{Mn}^{2+}[44,45]$. The latter apparently leads to faster oxidation and precipitation of Fe relatively Mn [46,47]. A notable trend of the Mn content growth in the upper layers of sediment cores at the hydrothermal field Pobeda, as well at the Petersburg field ( $\left.19^{\circ} 50^{\prime} \mathrm{N}, \mathrm{MAR}\right)$ [11], serve an obvious result of the increased oxidizing environment that are favorable to the Mn oxidation and precipitation there comparing to lower part of the cores where the Eh values were lowered due to influence of hydrothermal fluids.

A distinctive feature of the ore-bearing core $184 \mathrm{k}$ is a sharp increase, started from depth of 35, of the $\mathrm{Fe}, \mathrm{Cu}, \mathrm{Zn}, \mathrm{Pb}$, and As contents in natural sediment and in cfb, with the exception of Mn (Figure 4, Table S1). The examination of geochemical fractions showed that growth of $\mathrm{Fe}, \mathrm{Cu}$, and $\mathrm{Zn}$ contents in the lower part of the core $(35-70 \mathrm{~cm})$ was provided by a significant increase (three to five times in comparison to the above layers) of fraction F-2, the amorphous Fe-Mn oxyhydroxides (Figure 5). This fact is attributed to an influence of hydrothermal fluids of diffusive type which supply the ore metals into the sediments due to deep circulation systems hosted in ultramafic rocks at the Pobeda ore cluster. At the same time, beyond zone of hydrothermal activity, in background sediments of $215 \mathrm{k}$ core, metal partitioning between geochemical fractions showed no noticeable change in the down-core distribution (Figure 5). In both cores, $\mathrm{Mn}$ is the most labile metal whose accumulation was mostly provided ( $55 \%$ to $85 \%$ of total content) by the oxyhydroxides (fraction F-2).

In the background core 215k, a distribution patterns of metal geochemical fractions differ a little from those in the bottom sediments of the subarctic White and Arctic Barents Seas [48-51], as well as in the oxidized sediments of the Black Sea [52]. Manganese being a redox sensitive element in various geochemical environments, proved to be the most labile metal, whose sum of labile fractions is about $60 \%$ on average from its total contents.

The significant correlation relationships, the positive ones between Fe and the other ore metals (except Mn), and the negative ones between Fe and Mn, might suggest a main role of the Fe mineral phases in accumulation of the ore metals in metalliferous sediments. On the other hand, in the background carbonate sediment core $215 \mathrm{k}, \mathrm{Cu}, \mathrm{Zn}, \mathrm{Pb}$, and $\mathrm{As}$ exhibited a significant correlation with $\mathrm{Mn}$, that indicates their close association during accumulation in sediments, and the mineral phases of manganese can be considered as the main carriers of these ore metals.

Data on the distribution maps of elements (SEM micro-X-ray spectral analysis) in core $184 \mathrm{k}$, confirmed our assumption that in the ore-bearing sediments, a substitution of calcite foraminiferal shells with Fe in form of oxyhydroxides, mostly with goethite, took place (Figures 7 and 8). At the same time, in the background core 215k, such a replacement was not observed (Figure 9). 


\section{Conclusions}

The comparative research of geochemical and mineralogical data for the metalliferous sediment core from the Pobeda hydrothermal cluster and the background ones, let us to reveal some characteristic features in distribution of major and ore elements. In metalliferous sediment core $184 \mathrm{k}$, the down-core sharp decrease in the $\mathrm{CaCO}_{3}$ content $(77 \%$ to $20 \%)$, particularly at depth of 40-70 cm, was coherent with the maximal content of Fe oxyhydroxides $(44 \% \mathrm{cfb})$ in these deep layers. Such a character of down-core changes allowed us to assume that calcite was replaced with Fe oxyhydroxides, mostly, the hydrothermal goethite.

The data on distribution maps of elements in metalliferous core, support our suggestion about substitution of $\mathrm{Ca}$ in foraminiferal calcite tests with the $\mathrm{Fe}$ of oxyhydroxides. Such a character of change is obviously related to processes of metasomatic alteration of biogenic calcite induced by influence of the hydrothermal fluids. Meanwhile, in the background core, only an insignificant down-core change in $\mathrm{CaCO}_{3}$ content was observed, and the distribution maps exhibited a clear association of $\mathrm{Ca}$ and oxygen with foraminiferal calcite tests, while for Fe no such a relation was observed.

In the lower part (depth of 40-70 cm) of the metalliferous core, a sharp increase in total cfb contents of $\mathrm{Fe}, \mathrm{Cu}, \mathrm{Zn}, \mathrm{Pb}$, and $\mathrm{As}$, was recorded. At the same time, the down-core growth in the conditional geochemically mobile fractions $\mathrm{Fe}, \mathrm{Cu}$, and $\mathrm{Zn}$, as well as their residual form, that included the crystallized hydrothermal minerals and debris of modified ultramafic minerals, took place. This observation that might be attributed to influence of hydrothermal diffused fluids and fragments of transformed rocks.

The analysis of geochemical fractions of the ore metals confirms our previous research data on the important role of authigenic Fe oxyhydroxides, both amorphous and crystallized, in transformation of carbonate biogenic sediments into the ore-bearing ones. Our data suggest, that elevated accumulation of the ore metals occurred in contact zone of sediments with the underlying serpentinized peridotites.

Supplementary Materials: The following are available online at https:/ / www.mdpi.com/article / 10.3390/min11060591/s1, Table S1: Average contents of metals (ppm) in the selected geochemical fractions of metalliferous (st. 184k) and background (st. 215k) sediment cores, hydrothermal cluster Pobeda, the Mid-Atlantic Ridge $\left(17^{\circ} 07^{\prime}-17^{\circ} 08^{\prime} \mathrm{N}\right)$; Table S2: The XRD data on the mineral composition of sediment cores $215 \mathrm{k}$ and 184k from the hydrothermal cluster Pobeda, the Mid-Atlantic Ridge $\left(17^{\circ} 07^{\prime}-17^{\circ} 08^{\prime} \mathrm{N}\right)$; Table S3: Contents of ore metals (carbonate free base) in cores $184 \mathrm{k}$ and $215 \mathrm{k}$, and Spearman correlation coefficients for pairs of elements; Table S4: Sum of labile fractions F-1, F-2, and F-3 (percentage of total content) in the $184 \mathrm{k}$ and $215 \mathrm{k}$ sediment cores.

Author Contributions: L.D. interpreted the geochemical results, wrote the text; I.G. carried out sampling, interpreted the mineralogic analysis, wrote the text; O.D. performed the XRD analysis; D.B. performed the leaching procedures and AAS analysis; A.S. performed the XRF analysis; N.G. and T.S. performed a SEM-micro X-ray analysis. All authors have read and agreed to the published version of the manuscript.

Funding: This work was performed in accordance with the State Assignment of Ministry of Science and High Education, Russia, Programs No. № 0128-2021-0016 (Shirshov Institute of Oceanology, RAS) and No. 0135-2019-0050 (Geological Institute, RAS).

Acknowledgments: The authors are grateful to the captain and crew of cruise $37 \mathrm{R} / \mathrm{V}$ «Professor Logachev» for assistance in the cores sampling; to A.A. Laiba, V.E. Beltenev, and I.G. Dobretsova (VNII Sevmorgeology, St.-Petersburg) for lithological and mineralogical description of cores; as well as to N.A. Belyaev (Shirshov Institute of Oceanology, RAS, Moscow) for performing TOC and TIC analysis.

Conflicts of Interest: The authors declare no conflict of interests.

\section{References}

1. Skornyakova, N.S. The dispersed iron and manganese in the Pacific bottom sediments. Lithol. Min. Resour. 1964, 5, 3-20. (In Russian)

2. Boström, K.; Peterson, M.N.A. Precipitates from hydrothermal exhalations on the East Pacific Rise. Econ. Geol. 1966, 61, 1258-1265. [CrossRef] 
3. Bonatti, E. Mechanism of deep-sea volcanism in the South Pacific. Res. Geochem. 1967, 2, 215-221.

4. Boström, K. The origin and fate of ferromanganese active ridge sediments. Stockh. Contrib. Geol. 1973, XXVII, 148-243.

5. Lisitzin, A.P.; Bogdanov, Y.A.; Gurvich, E.G. The Hydrothermal Deposits in the Ocean. Rift Systems; Nauka: Moscow, Russia, 1990; 248p. (In Russian)

6. Lisitzin, A.P. The Hydrothermal systems of the World Ocean: Input of endogenous substance. In Hydrothermal Systems and Sedimentary Formation of the Mid-Ocean. Ridges; Nauka: Moscow, Russia, 1993; pp. 147-245. (In Russian)

7. Gurvich, E.G. Metalliferous Sediments of the World Ocean: A Fundamental Theory of Deep-Sea Hydrothermal Sedimentation; Kirchner, E., Ed.; Springer: Berlin/Heidelberg, Germany, 2006; 413p.

8. German, C.R.; Von Damm, K.L. Hydrothermal processes. In Treatise on Geochemistry; Turekian, K., Holland, H., Eds.; Elsevier: Amsterdam, The Netherlands, 2004; pp. 181-222.

9. Mills, R.A.; Elderfield, H. Hydrothermal activity and geochemistry of metalliferous sediments. Geophys. Monogr. 1995, 91, 392-407.

10. Rona, P.A. Hydrothermal mineralozation at seafloor spreading center. Earth Sci. Rew. 1984, 20, 1-104. [CrossRef]

11. Gablina, I.F.; Dmitrenko, O.B.; Oskina, N.S.; Khusid, T.A.; Popova, E.A. Impact of hydrothermal activity on carbonate microfossils in bottom sediments of the tropical Atlantic. Oceanology 2015, 55, 100-111. [CrossRef]

12. Gablina, I.F.; Demina, L.L.; Dmitrenko, O.B.; Oskina, N.S.; Popova, E.A.; Khusid, T.A.; Shilov, V.V. The composition, distribution, and features of the post sedimentation alteration of microfossils from the recent bottom sediments of hydrothermal field Ashadze-1 (13 N, MAR). Oceanology 2011, 51, 505-520. [CrossRef]

13. Boyle, E.A. Cadmium, zinc, copper, and barium in foraminifera tests. Earth Planet. Sci. Lett. 1981, 53, 11-35. [CrossRef]

14. Demina, L.L.; Oskina, N.S. The new data on elemental composition of planktonic foraminifera microfossils of the Atlantic Ocean. Dokl. Earth Sci. 2016, 471, 224-229. [CrossRef]

15. Hein, J.R.; Mizell, K.; Koschinsky, A.; Conrad, T.A. Deep-ocean mineral deposits as a source of critical metals for high- and green-technology applications: Comparison with land-based resources. Ore Geol. Rev. 2013, 51, 1-14. [CrossRef]

16. Sukhanova, A.; Firstova, A.; Stepanova, T.; Cherkashov, G. Uranium in seafloor massive sulfides at the Mid-Atlantic Ridge. In Proceedings of the Sustainable Development of Seabed Mineral Resources: Environment, Regulations and Technologies, UMS 2019 48th Underwater Mining Conference, Sanya, China, 22 September 2019; p. 3.

17. González, F.J.; Rincón-Tomás, B.; Somoza, L.; Santofimia, E.; Medialdea, T.; Madureira, P.; López-Pamo, E.; Hein, J.R.; Marino, E.; de Ignacio, C.; et al. Low-temperature, shallow-water hydrothermal vent mineralization following the recent submarine eruption of Tagoro volcano (El Hierro, Canary Islands). Mar. Geol. 2020, 430, 106333. [CrossRef]

18. Somoza, L.; González, F.J.; Barker, S.J.; Madureira, P.; Medialdea, T.; de Ignacio, C.; Lourenço, N.; León, R.; Vázquez, J.T.; Palomino, D. Evolution of submarine eruptive activity during the 2011-2012 El Hierro event as documented by hydro-acoustic images and remotely operated vehicle observations. Geochem. Geophys. Geosyst. 2017, 18, 3109-3137. [CrossRef]

19. Marino, E.; González, F.J.; Kuhn, T.; Madureira, P.; Wegorzewski, A.V.; Mirao, J.; Medialdea, T.; Oeser, M.; Miguel, C.; Reyes, J.; et al. Hydrogenetic, Diagenetic and Hydrothermal Processes Forming Ferromanganese Crusts in the Canary Island Seamounts and Their Influence in the Metal Recovery Rate with Hydrometallurgical Methods. Minerals 2019, 9, 439. [CrossRef]

20. Gablina, I.F.; Dobretsova, I.F.; Beltenev, V.E.; Lyutkevich, A.D.; E., V.; Narkevskii, E.V.; Gustaitis, A.N. Peculiarities of modern sulfide mineralization at $19^{\circ} 15^{\prime}-20^{\circ} 08^{\prime} \mathrm{N}$, Mid Atlantic Ridge. Dokl. Earth Sci. 2012, 442, 163-167. [CrossRef]

21. Gablina, I.F.; Popova, E.A.; Sadchikova, T.A.; Savichev, A.T.; Gor'kova, N.V.; Os'kina, N.S.; Khusid, T.A. Hydrothermal metasomatic alteration of carbonate bottom sediments in the Ashadze-1 field (13 ${ }^{\circ} \mathrm{N}$ Mid-Atlantic Ridge). Geol. Ore Depos. 2014, 56, 357-379. [CrossRef]

22. Gablina, I.F.; Dobretsova, I.G.; Narkevskii, E.V.; Gustaitis, A.N.; Sadchikova, T.A.; Gor'kova, N.V.; Savichev, A.T.; Lyutkevich, A.D.; Dara, O.M. Influence of hydrothermal-metasomatic processes on the formation of present-day sulfide ores in carbonate bottom sediments at the Mid-Atlantic Ridge $\left(19^{\circ}-20^{\circ}\right.$ N). Lithol. Min. Resour. 2017, 52, 335-357. [CrossRef]

23. Gablina, I.F.; Dobretsova, I.G.; Popova, E.A.; Dara, O.M.; Sadchikova, T.A.; Gor'kova, N.V.; Mikheev, V.V. Mineral composition and geochemical zoning of bottom sediments of the Pobeda hydrothermal cluster $\left(17^{\circ} 07.45^{\prime} \mathrm{N}-17^{\circ} 08.7^{\prime} \mathrm{N}, \mathrm{Mid}^{-A t l a n t i c}\right.$ Ridge $)$. Lithol. Min. Resour. 2021, 56, 113-131. [CrossRef]

24. Beltenev, V.E.; Narkevsky, E.V.; Dobretsova, I.G.; Gablina, I.F.; Galkin, S.V.; Molodtsova, T.N.; Layba, A.A. The results of Professor Logatchev-37 cruise, MAR. In Proceedings of the XXI International Scientific Conference (School) on Marine Geology, Moscow, Russia, 16-20 November 2015; GEOS: Moscow, Russia, 2015; pp. 126-128. (In Russian).

25. Beltenev, V.E.; Rozhdestvenskay, I.I.; Samsonov, I.K. Exploration Work on the Russian Exploration Area in the Atlantic Ocean with an Estimate Forecast Resources of GPS of Categories P2 and P3 in Blocks 31-Report of Professor Logachev-37 Cruise; Lomonosov, Russia; PMGRE: Saint Petersburg, Russia, 2016. (In Russian)

26. Gablina, I.F.; Dobretsova, I.G.; Layba, A.A.; Narkevskii, E.V.; Maksimov, F.E.; Kuznetsov, V.Y. Features of sulfide ores at hydrothermal cluster Pobeda $\left(17^{\circ} 07.45^{\prime} \mathrm{N}-17^{\circ} 08.7^{\prime} \mathrm{N}\right.$, the Mid-Atlantic Ridge). Lithol. Min. Resour. 2018, 6, 1-26. [CrossRef]

27. Maslennikov, V.V.; Cherkashov, G.A.; Artemyev, D.A.; Firstova, A.R.; Large, R.R.; Tseluyko, A.; Kotlyarov, V. Pyrite varieties at

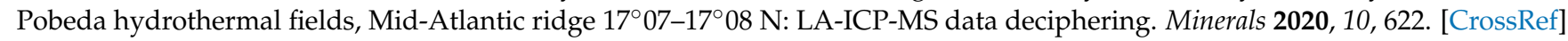

28. Bich, A.S.; Petrov, Y.A. Study of the ore-bearing sediments to reconstruct processes of hydrothermal tore formation (on the example of the Pobeda hydrothermal cluster, MAR). In Proceedings of the Scientific Conference on Metallogeny of the Ancient and Modern Oceans. Institute of Mineralogy UD RAS, Miass, Russia, 12-15 April 2018; pp. 117-127. (In Russian). 
29. Krasnov, S.G.; Cherkashov, G.A.; Ainemer, A.I.; Grintal, E.F.; Grichuk, D.V.; Davidov, M.P. Hydrothermal Sulfide Ores and Metalliferous Sediments in the Ocean; Nedra: Saint-Petersburg, Russia, 1992; 278p. (In Russian)

30. Amplieva, E.E.; Bortnikov, N.S.; Kovalchuk, E.V.; Beltenev, V.E. The Pobeda modern submarine hydrothermal sulfide edifice cluster (Mid-Atlantic Ridge, 17 08' N): Mineralogy and chemical composition. In Proceedings of the 14th SGA Biennial Meeting. Mineral Resources to Discover, Quebec Citi, QC, Canada, 20-23 August 2017; Volume 1-4, pp. 649-652.

31. Tessier, A.; Campbell, P.G.C.; Bisson, M. Sequential extraction procedure for the speciation of particulate trace metals. Anal. Chem. 1979, 51, 844-851. [CrossRef]

32. Ure, A.M.; Quevauviller, P.; Muntau, H.; Griepink, B. Speciation of heavy metals in soils and sediments. An account of the improvement and harmonization of extraction techniques undertaken under the auspices of the BCR of the Commission of the European Community. Int. J. Environ. Anal. Chem. 1993, 51, 135-151. [CrossRef]

33. Luoma, S.N.; Bryan, G.W. A statistical assessment of the forms of trace metals in oxidized estuarine sediments employing chemical extractants. Sci. Total Environ. 1981, 17, 165-196. [CrossRef]

34. Chester, R.; Hughes, M.J. A chemical technique for separation of ferromanganese minerals and adsorbed trace metals from pelagic sediments. Chem. Geol. 1967, 3, 249-262. [CrossRef]

35. Kitano, Y.; Fujiyoshi, R. A selective chemical leaching of $\mathrm{Cd}, \mathrm{Cu}, \mathrm{Mn}$ and Fe in marine sediments. Geochem. J. 1980, 14, 122-128. [CrossRef]

36. Quevauviller, P.; Ure, A.; Muntau, H.; Griepink, B. Improvement of analytical measurements within the BCR programme: Single and sequential extraction procedures applied to soil and sediment analysis. Int. J. Environ. Anal. Chem. 1993, 51, 129-134. [CrossRef]

37. Pueyo, M.; Rauret, G.; Lück, D.; Yli-Halla, M.; Muntau, H.; Quevauviller, P.; López-Sánchez, J.F. Certification of the extractable contents of $\mathrm{Cd}, \mathrm{Cr}, \mathrm{Cu}, \mathrm{Ni}, \mathrm{Pb}$ and $\mathrm{Zn}$ in a freshwater sediment following a collaboratively tested and optimized three-step sequential extraction procedure. J. Environ. Monit. 2001, 3, 243-250. [CrossRef]

38. Sutherland, R.A.; Tack, F.M.G. Fractionation of $\mathrm{Cu}, \mathrm{Pb}$ and $\mathrm{Zn}$ in certified reference soils SRM 2710 and SRM 2711 using the optimized BCR sequential. Adv. Environ. Res. 2003, 8, 37-50. [CrossRef]

39. Moore, D.M.; Reynolds, R.C. X-ray Diffraction and the Identification and Analysis of Clay Minerals, 2nd ed.; Oxford University Press: Oxford, UK; New York, NY, USA, 1997; 378p.

40. Gerasimov, V.N.; Dolivo-Dobrovolskaya, E.M.; Kamentsev, I.E.; Kondratyeva, V.V.; Kosoy, A.L.; Lesyuk, G.I.; Rozhdestvenskaya, I.V.; Stroganov, E.V.; Filatov, S.K.; Frank-Kamenetskaya, O.V. Guide to X-ray Analysis of the Main Types of Rock-Forming Minerals; UDC: 548.73; Nedra: Leningrad, Russia, 1975; 399p. (In Russian)

41. Butusova, G.Y. Types of modern hydrothermal and hydrothermal-sedimentary deposits in the active zone of the World Ocean. Lithol. Miner. Resour. 1989, 5, 3-24.

42. Rudnick, R.L.; Gao, S. Composition of the continental crust. In Treatise on Geochemistry; Holland, H.D., Turekian, K.K., Eds.; Elsevier: Amsterdam, The Netherlands, 2004; Volume 3, pp. 1-64.

43. Lisitzin, A.P. The Sedimentation Processes in the Ocean; Nauka: Moscow, Russia, 1978; 392p. (In Russian)

44. Krauskopf, K.B. Separation of manganese and iron in sedimentary processes. Geochim. Cosmochim. Acta. 1957, 12, 61-84. [CrossRef]

45. Froelich, P.N.; Klinkhammer, G.P.; Bender, M.L.; Luedtke, N.A.; Heat, G.R.; Cullen, D.; Daupgin, P.; Hammond, D.; Hartmann, B.; Maynard, V. Early oxidation of organic matter in pelagic sediments of the eastern equatorial Atlantic: Suboxic diagenesis. Geochim. Cosmochim. Acta 1979, 43, 1075-1090. [CrossRef]

46. Postma, D. Concentration of $\mathrm{Mn}$ and separation from Fe in sediments-I. Kinetics and stoichiometry of the reaction between birnessite and dissolved Fe(II) at $10{ }^{\circ} \mathrm{C}$. Geochim. Cosmochim. Acta 1985, 49, 1023-1033. [CrossRef]

47. Burdige, D.J. The biogeochemistry of manganese and iron reduction in marine sediments. Earth-Sci. Rev. 1993, 35, 249-284. [CrossRef]

48. Demina, L.L.; Bud'ko, D.F.; Alekseeva, T.N.; Novigatsky, A.N.; Filippov, A.S.; Kochenkova, A.I. Partitioning of trace elements in the early diagenesis of bottom sediments in the White Sea. Geochem. Int. 2017, 55, 144-149. [CrossRef]

49. Budko, D.F.; Demina, L.L.; Lisitzin, A.P.; Kravchishina, M.D.; Politova, N.V. The occurrence forms of heavy metals in the recent sediments of the White and Barents Seas. Dokl. Earth Sci. 2017, 474, 93-98. [CrossRef]

50. Demina, L.L.; Budko, D.F.; Novigatsky, A.N.; Alexseeva, T.N.; Kochenkova, A.I. Occurrence forms of heavy metals in the bottom sediments of the White Sea. In Handbook of Environmental Chemistry. Sedimentation Processes in the White Sea: The White Sea Environment Part II; Lisitsyn, A.P., Demina, L.L., Eds.; Springer International Publishing AG: Cham, Switzerland, 2018; pp. 241-270. [CrossRef]

51. Demina, L.L.; Dara, O.M.; Aliev, R.D.; Alekseeva, T.N.; Budko, D.F.; Novichkova, E.A.; Politova, N.V.; Solomatina, A.S.; Bulokhov, A.V. Elemental and mineral composition of the Barents Sea recent and Late Pleistocene-Holocene sediments: A correlation with environmental conditions. Minerals 2020, 10, 593. [CrossRef]

52. Nemchenko, E.I.; Lipatnikova, O.A.; Demina, L.L.; Kravchishina, M.D.; Lubkova, T.N. The distribution of elements in the vertical section of bottom sediments in the Black Sea. Mosc. Univ. Geol. Bull. 2020, 75, 168-176. [CrossRef] 